Boston University School of Law Scholarly Commons at Boston University School of Law

Faculty Scholarship

$11-2015$

\title{
Fairness at a Time of Perplexity: The Civil Law Principle of Fairness in the Court of Justice of the European Union
}

Daniela Caruso

Boston Univeristy School of Law

Follow this and additional works at: https://scholarship.law.bu.edu/faculty_scholarship

Part of the European Law Commons

\section{Recommended Citation}

Daniela Caruso, Fairness at a Time of Perplexity: The Civil Law Principle of Fairness in the Court of Justice of the European Union, Boston University School of Law, Public Law Research Paper (2015).

Available at: https://scholarship.law.bu.edu/faculty_scholarship/150 
DANIELA CARUSO ${ }^{1 *}$

FAIRNESS AT A TIME OF PERPLEXITY:

THE CiVIL LAW PRINCIPLE OF FAIRNESS IN THE COURT OF JUSTICE OF

THE EUROPEAN UNION**

1. Introduction

The title of this essay is loosely modeled upon the work of Thomas M. Franck, an influential international law scholar preoccupied with the notion of fairness. ${ }^{2}$ In Franck's writings, fairness was portrayed as a relative and indeterminate concept. ${ }^{3}$ At times, however, the author seemed to revert to a foundationalist defense of fairness as a distinctive trait of advanced legal systems, setting them apart from chaotic and despotic regimes. ${ }^{4}$ While remote from present-day European troubles, Franck's oscillation captures the spirit of the time in EU legal discourse. On one hand, disenchantment with the EU legal project as an instrument of justice is on the rise. ${ }^{5}$ Trenchant critiques have been aimed at the very design of 'integration through law,' which has proven structurally unable to cure problems in the socio-economic peripheries of the Union, ${ }^{6}$ has failed at creating true post-national cohesion, ${ }^{7}$ and seems founded on a false or framed mode of democratic deliberation. ${ }^{8}$ In the particular context of private law, a growing body of literature is casting doubts on the ability of EU-led consumer protection to correct the inequities of Europe's markets,

* Professor of Law, Boston University School of Law and Center for the Study of Europe. Thanks to Marija Bartl, Bianca Gardella-Tedeschi, Steven Garza, Duncan Kennedy, Fernanda Nicola, and Mark Pettit for comments on earlier drafts. Errors are mine.

** Forthcoming in S. Vogenauer and S. Weatherill Eds., General Principles of Law: European and Comparative Perspectives, Hart 2016.

2 TM Franck, Fairness in International Law and Institutions (Oxford University Press, 1998); TM Franck, 'Epistemology at a Time of Perplexity’ (2002) 13 European Journal of International Law 1025 (defending fairness against cultural relativism).

${ }^{3}$ Franck, Fairness, (n 2) 14 ("[F]airness is relative and subjective . . . a human, subjective, contingent quality....”).

${ }^{4}$ See E MacDonald, International Law and Ethics after the Critical Challenge: Framing the Legal within the Post-Foundational (2011) 220-221 (documenting this shift in Franck's writings); I Scobbie, ‘Tom Franck’s Fairness' (2002) 13 European Journal of International Law 909.

5 D Kochenov, G de Burca, and A Williams (eds), Europe's Justice Deficit? (Hart Publishing, 2014).

${ }^{6}$ D Kukovec, 'Law and the Periphery' (2014) 21 European Law Journal 406.

7 JHH Weiler, 'Van Gend en Loos: The Individual as Subject and Object and the Dilemma of European Legitimacy’ (2014) 12 International Journal of Constitutional Law 94, 103.

${ }^{8} \mathrm{M}$ Bartl, 'Internal Market Rationality, Private Law and the Direction of the Union: Resuscitating the Market as the Object of the Political' (2015) 21 European Law Journal 572. 
especially in the aftermath of the crisis and in light of the structural dynamics of legal integration. ${ }^{9}$

On the other hand, jurists seem unable to relinquish faith in fairness, or justice, as a plausible aspiration of the EU legal system - a guiding principle, procedural and discursive if not substantive, which EU law should, and can, uphold because the world would certainly be worse without it. ${ }^{10}$ The depth of interdependence between member states, reached through free trade and centralized policies over the past six decades, has disabled a number of domestic justice mechanisms, ${ }^{11}$ with the result that if no justice can be found on the EU plane, all hope is lost. ${ }^{12}$ The chasm between faith and skepticism runs deep, not only between various scholarly camps, but also among scholars of similar persuasion, and even within the body of single authors' contributions. ${ }^{13}$

The general principle of fairness, recently articulated by the Court of Justice of the European Union ("CJEU”), is bound to prompt exactly this sort of ambivalence among scholars. Fairness in private law could be dismissed as hopelessly indeterminate: yet another venue of judicial balancing, a technique already seen ad nauseam in Luxembourg, whereby lip service is paid to conflicting considerations, but no real solace can be found against regressive outcomes of law and policy choices. ${ }^{14}$ At the same time, the judicial articulation of a general principle of fairness in private law could be seen as a prompt for domestic courts to entertain context-sensitive considerations, in such a way as to redress, within the boundaries of judicial discretion, the predicaments of situationally disadvantaged parties. A Rawlsian reading of fairness would point precisely in this direction. ${ }^{15}$ Particularized, policy-oriented inquiries into the distributive stakes of each dispute, such as the relative impact upon low-income subjects of (in)validating certain contract terms or (dis)allowing certain remedies, could ultimately raise the standards of substantive justice in the EU. ${ }^{16}$

\footnotetext{
${ }^{9}$ See D Caruso, 'Qu'ils mangent des contrats: Rethinking Justice in EU Contract Law' in D Kochenov (ed), Europe’s Justice Deficit? (Hart Publishing, 2014) 367 (surveying this literature).

${ }^{10}$ See O Gerstenberg, 'Constitutional Reasoning in Private Law: The Role of the CJEU in Adjudicating Unfair Terms in Consumer Contracts’ (2015) 21 European Law Journal 599 (providing a theoretical framework and a comprehensive analysis of the CJEU's case law on fairness in $\mathrm{B} 2 \mathrm{C}$ relations).

${ }^{11}$ A Somek, The Cosmopolitan Constitution (Oxford University Press, 2014).

12 J Habermas, The Crisis of the European Union: A Response (Polity, 2013).

${ }^{13}$ See Section 9.

${ }^{14}$ M Lasser, 'Fundamentally Flawed: The CJEU's Jurisprudence on Fundamental Rights and Fundamental Freedoms’ (2014) 15 Theoretical Inquiries Law 229.

15 J Rawls, A Theory of Justice (Harvard University Press, 1971) 76.

${ }^{16}$ LA Fennell and RH McAdams, 'The Distributive Deficit in Law and Economics' (2016) 100 Minnesota Law Review (providing examples of distribution- sensitive judicial reasoning in contracts and other areas of law).
} 
These pages, based on the premise that distributive analysis in private law adjudication is desirable, set forth the argument that the CJEU has recently proven capable of identifying distributive trade-offs in the name of fairness, that such uses of judicial discretion do not exceed the scope of the court's institutional competence, and that the Court should not retreat from this laudable path. To be sure, at times the Court has also misused the idea of fairness, reducing it to an empty representational device through which facile slogans could unduly displace serious distributive analysis. ${ }^{17}$ Nevertheless, the Court's occasional embrace of the principle in substantive terms deserves attention and praise. In the midst of sobering reflections on law's complicity in perpetuating Europe's inequalities, it may be important to take stock of narrow, but clear, progress through law. ${ }^{18}$

As a result of fairness-driven holdings in Luxembourg, state legislators have already faced considerable pressure to control aggressive debt collection practices in austerity-ridden countries. ${ }^{19}$ Progress results as well from the inter-institutional dialogue increasingly triggered by the supranational regulation of private autonomy. ${ }^{20}$ The transmission belt that connects the Troika's recipes for growth to the member state governments' austerity reforms is notoriously rigid and leaves little room for textured accounts of its social consequences. It is in the context of contract law adjudication that, by contrast, such accounts find a stage. The post-crisis anecdotes of private misery that are found in the litigation of contract disputes acquire not just visibility, but also legal, justiciable form. Shoring up such hard-won expressive outlets in the face of countervailing messages is essential.

The argument proceeds as follows. Section 2 outlines the CJEU's 'discovery' of fairness as a general principle of civil law in the path breaking case $E$ Friz. ${ }^{21}$ Section 3 equates the general principle of fairness with distribution-sensitive adjudication, and illustrates how the CJEU's balancing of conflicting interests in its preliminary rulings could be regularly informed by lucid forms of distributive analysis. Section 4 posits that, given the conceptual and systemic autonomy of civil law principles, judicial fairness can radiate meaning beyond the confines of B2C disputes and onto broader inequality debates without any undue blurring of canonical partitions (private/constitutional, legal/political).

\footnotetext{
17 See Section 7.

${ }^{18}$ See U Mattei and F Nicola, 'A “Social Dimension” in European Private Law? The Call for Setting a Progressive Agenda’ (2006) 41 New England Law Review 1.

${ }^{19}$ See Section 4.

20 ibid.

${ }^{21}$ Case-215/08 E Friz GmbH v. von der Heyden [2010] E.C.R. I-2947, ๆ 48.
} 
By way of comparison, Section 5 identifies several functional equivalents of the general principle of fairness in U.S. contracts adjudication and recounts their rise and fall. Section 6 shows how the decline of judicial fairness has led U.S. progressive jurists to pursue the goal of fairer transactions outside of court, and points to the downsides of excising fairness from contracts adjudication. On the basis of this assessment, Section 7 affirms the usefulness of a judicial principle of fairness in supranational private law, but it cautions the CJEU against resorting to false or facile dichotomies in the balancing exercise that fairness requires.

The essay concludes by joining an emerging strand in current legal scholarship. This strand remains critical of the shortcomings of the EU legal architecture from the perspective of distributive justice, and yet clings to law - as both process and substance - whenever law can effectively fence off two ongoing phenomena: the deployment of economic dogma as a conversation stopper in policy-making circles, discussed in Section 8, and the endless proliferation of 'unweighted' narratives in EU discourse, which are too often balanced against one another as if they all had equal importance and legitimacy (Section 9).

\section{Discovering Fairness}

In recent years, the CJEU has worked on the assumption that a general principle of fairness must guide the adjudication of disputes between private parties. In E Friz, a path-breaking case decided at the dawn of this decade, the Court held that it is "in accordance with the general principles of civil law [to ensure] a satisfactory balance and a fair division of the risks among the various interested parties." 22 The CJEU did so while interpreting a text that, contrary to the directives on Unfair Contract Terms (UCT) and on Unfair Commercial Practices (UCP), did not adopt fairness as a central concept and only referred to it obliquely. ${ }^{23}$ While arguably in line with the ample set of CJEU cases that embrace a thick notion of consumer protection, ${ }^{24}$ this was a judicial move of a different order of magnitude. At stake in E Friz was not just the normal practice of providing authoritative readings of secondary legislation when the statutory text calls for fairness in particular contractual contexts. Rather, identifying fairness

\footnotetext{
22 ibid (emphasis added).

${ }^{23}$ Directive 85/577/EEC of 20 December 1985 of the European Economic Community to protect the consumer in respect of contracts negotiated away from business premises (referring only once in its preamble to a 1974 preliminary programme of the European Economic Community for a consumer protection and information policy, which asked "that appropriate measures be taken to protect consumers against unfair commercial practices in respect of doorstep selling.").

${ }^{24}$ V Trstenjak and E Beysen, 'European Consumer Protection Law: Curia Semper Dabit Remedium?’ (2011) 48 Common Market Law Review 95.
} 
as a result of general principles of civil law meant adopting it as a plausible interpretive aid whenever applicable laws do not lend the judge precise guidance.

The facts and the law of the $E$ Friz case have been thoroughly analyzed by other scholars, making a full summary here redundant. ${ }^{25}$ In brief, in 1991 Mr. von der Heyden had received an unsolicited visit by a tax consultant who had convinced him to invest, together with other partners, in the modernization of decrepit real estate in Berlin. For contracts concluded in this haphazard fashion, the EU door-step selling directive grants consumers a right to repent, i.e. to cancel the deal in a period of no less than seven days from due notice of this right. ${ }^{26}$ If the consumer receives no such notice - as was the case here - the possibility to cancel lasts longer. ${ }^{27}$ Accordingly, Mr. von der Heyden withdrew from the partnership in 2002, after a period of over 10 years, hoping to recoup the full value of his investment on restitutionary grounds. The partnership, however, refused to refund Mr. von der Heyden, and asked instead that he pay them over $€ 13,000$ - the negative difference between his original investment and his share of the steep losses suffered by the partnership over the years. This result would be in compliance with German law, and in particular with the judge-made principle of 'defective partnership,' duly highlighted for the CJEU by AG Trstenjak in her opinion. ${ }^{28}$

The language used by the Court to endorse the latter result is worth quoting in full:

48 As the Bundesgerichtshof observed in its decision for reference, [the German] rule is intended to ensure, in accordance with the general principles of civil law, a satisfactory balance and a fair division of the risks among the various interested parties.

49 Specifically, first, such a rule offers the consumer cancelling his membership ... the opportunity to recover his holding, while taking on a proportion of the risks inherent to any capital investment of the type at issue in the main proceedings. Secondly, it also enables the other partners or third party creditors ... not to have to bear the financial consequences of the cancellation of that membership, which moreover occurred following the signature of a contract to which they were not party. ${ }^{29}$

\footnotetext{
25 See MW Hesselink, 'The General Principles of Civil Law: Their Nature, Roles and Legitimacy' in D Leczykiewicz and S Weatherill (eds), The Involvement of EU Law in Private Law Relationships 131 (Hart Publishing, 2013).

${ }^{26}$ Directive 85/577/EEC (n 23).

${ }^{27}$ Case C-481/99 Heininger v. Bayerische Hypo- und Vereinsbank AG [2001] E.C.R. I09945; Case-412/06 Annelore Hamilton v. Volksbank Filder eG. [2008] E.C.R. I-02383 (discussing the issue of limitation on the time for repentance).

${ }^{28}$ E Friz, [2010] E.C.R. I-2947.

29 ibid.
} 
The Court's promotion of fairness to the rank of general principle of civil law in the context of E Friz is highly meaningful to the development of EU law. The Court decided this case in 2010 - two full years into the financial crisis, at a time in which consumers all over Europe and beyond shared Mr. von der Heyden's desire to walk back from improvident investments. ${ }^{30}$ The jurists who wrote the $E$ Friz judgment were surrounded by news of pervasive financial disasters, and were constantly reminded that the consequences of poor financial market regulation would hit some pockets of the EU population much more heavily than others. This was fertile terrain for the judicial discovery of a principle of fairness ${ }^{31}-\mathrm{a}$ principle that had not been named either by the referring court or by the Advocate General, and that was invoked sua sponte by the CJEU. Apportioning losses fairly, i.e. protecting those who were hopelessly stuck with the partnership from the sudden flight of those who could withdraw their membership, seemed to be what justice required. The Court decided accordingly.

To be sure, a narrow reading of the case is also possible: the decision could have been merely a pluralist embrace of Germany's own partnership law, developed by German judges on the basis of German principles. Besides, according to the door-step selling directive, the restitutionary consequences of withdrawal must be determined by national law, and the CJEU had little choice but to defer to the German definition of such remedies. But the language of the Court goes beyond mere judicial necessity. It is a language of solidarity between those who could flee and those left behind in the quagmire of financial disaster. It is at least plausible that the judges could see the analogy between the uneven distribution of losses inside the E Friz partnership on one hand, and Europe's larger inequities on the other: the widening of the spreads, the predicament of the PIIGS, and the plight of the unemployed.

\section{Fairness as distributive justice}

Another reason why the judgment is momentous is that it embraces a substantive - as opposed to procedural or discursive - notion of fairness. The interests of all the parties to the E Friz dispute were not just formally

\footnotetext{
${ }^{30}$ AG Trstenjak pointed out that "Investment in [junk] property, which Germans opted for primarily on account of the resultant tax benefits, has often failed to deliver the expected results, and investors have therefore looked for ways of terminating those investments by relying inter alia on the Community directives concerning consumer protection.” E Friz, [2010] E.C.R. I-2947, ๆ 3.

${ }^{31} \mathrm{~K}$ Lenaerts and JA Gutiérrez-Fons, 'The Constitutional Allocation of Powers and General Principles of EU Law’ (2010) 47 Common Market Law Review 1629, 1635 (referring to judicial 'discovery' of general principles, which are assumed to pre-exist in the legal system of reference).
} 
represented in the opinion, but tangibly recognized in the outcome and in the way the loss from poor investments was apportioned between affected investors. Adopting a fairness principle of this sort signals openness to distributive justice in contract law and departs from philosophical or utilitarian approaches that reduce contract exclusively to 'promise' or 'efficiency.'32

The question whether distributive considerations really belong in private law adjudication continues to animate legal scholarship. ${ }^{33}$ Many object to distributive justice as a goal of contract law, either because of adherence to the view - based on legal philosophy- that contracts enforcement should cling to corrective justice only, ${ }^{34}$ or because of the conviction that distributive justice is more efficiently achieved through taxation and other forms of transfers, as opposed to adjudication of private disputes. ${ }^{35} \mathrm{~A}$ complete refutation of these arguments exceeds the scope of this paper, but abundant counter-arguments exist in theoretical literature. ${ }^{36}$ Foremost among such arguments is the finding that, as a matter of positive law, redistributive motives are already pervasive in the law of contracts, and that many rules and doctrines cannot be understood without resorting to substantive fairness. ${ }^{37}$ Fairness competes with other values for primacy, but it is obviously in the race.

Fairness is regularly balanced against other values in the system, while also nesting within itself an evaluation of relative costs and benefits. In a Rawlsian sense, fairness requires aiding "the least advantaged," 38 which in contract law means minimizing the negative impact of rules on those who would lose the most due to background unfairness. Whenever an interpretive gap leaves the judge room for maneuver, a lucid assessment of circumstances and distributive considerations must precede and guide the adjudicatory process. Flattening the fairness mandate onto a contextindifferent plane, as if all consumers and traders deserved invariant amounts of autonomy and protection, would not promote substantive

32 See A Bagchi, 'Distributive Justice and Contract' in G Klass and others (eds), Philosophical Foundations of Contract Law 193 (Oxford University Press, 2015) (providing a persuasive account of reasons to adjudicate contract disputes in light of distributive justice, and a full survey of relevant literature).

${ }^{33}$ Fennell and McAdams 'The Distributive Deficit in Law and Economics'.

${ }^{34}$ EJ Weinrib, The Idea of Private Law (Harvard University Press, 1995).

${ }^{35}$ L Kaplow and S Shavell, 'Why the Legal System Is Less Efficient than the Income Tax in Redistributing Income’ (1994) 23 Journal Legal Studies 667. cf Fennell and McAdams, 'The Distributive Deficit in Law and Economics' (providing a thorough critique of the assumption that taxation is always a preferable strategy for wealth redistribution).

${ }^{36}$ Bagchi (n 32).

${ }^{37}$ D Kennedy, 'Distributive and Paternalist Motives in Contract and Tort Law, with Special Reference to Compulsory Terms and Unequal Bargaining Power’ (1982) Maryland Law Review 563.

38 J Rawls, 'Justice as Fairness: Political not Metaphysical' (1985) 14 Philosophy and Public Affairs 223. 
justice. $^{39}$ A contextualized and distribution-sensitive reading of the fairness principle in court is a necessary (though not sufficient) antidote to the ongoing re-formalization of private law - a process in which, for the sake of the internal market, the EU legal system creates new average groups and reinterprets justice as market access. ${ }^{40}$

A paradigmatic example of judicial balancing, based on thoughtful distributive considerations, is to be found in Justice Brennan's opinion in Penn Central v. New York. ${ }^{41}$ Following denial of a permit to build above the existing station's structure, appellants sought monetary compensation based on the idea that zoning regulation (in particular, the preservation of historic landmarks) had resulted in the taking of their jus aedificandi. Famously, Brennan noted that the City's preservation of historic landmarks over time was the very reason for the enormous value of Penn Central's property. In the balancing of property rights against public interest, it became therefore clear that appellants derived great advantage from the very regulatory practice that they deemed harmful, and deserved, as a consequence, no compensation. ${ }^{42}$

The mode of judicial reasoning adopted in Penn Central may strike some European observers as excessively open-ended, but it is hard to see how the dispute could be seriously resolved without resort to Brennan's distributive logic. A lucid consideration of benefits and harms is not beyond the realm of judicial functions, but is rather essential to an intelligent adjudication of each case. A distributive analysis of the type performed in E Friz in application of the door-step selling directive confirms the plausibility of a distribution-sensitive application of fairness in judgment. The consideration of the situational predicaments of all creditors affected by Mr. von der Heyden's withdrawal added to the clarity of the judgment, allowed for context-tailored application of pro-consumer legislation, and avoided one-sided results that might go against the intent of the EU legislator.

\footnotetext{
${ }^{39}$ Kukovec (n 6).

40 Bartl, 'Internal Market Rationality, Private Law and the Direction of the Union: Resuscitating the Market as the Object of the Political' (n 8) 586 (explaining that EU private law, in the name of the Internal Market, has "creat[ed] new average groups and [stressed] procedural rights rather than substantive protection[,]” thereby eclipsing substantive justice).

${ }^{41}$ Penn Cent. Transp. Co. v. City of New York, 438 U.S. 104 (1978).

42 ibid 147 ("Even where the government prohibits a noninjurious use, the Court has ruled that a taking does not take place if the prohibition applies over a broad cross section of land and thereby "secure[s] an average reciprocity of advantage." Pennsylvania Coal Co. v. Mahon, 260 U.S., at 415, 43 S.Ct. at $160 \ldots$. It is for this reason that zoning does not constitute a "taking.” While zoning at times reduces individual property values, the burden is shared relatively evenly and it is reasonable to conclude that on the whole an individual who is harmed by one aspect of the zoning will be benefited by another.”).
} 


\section{The Expressive Function of Judicial Fairness}

As noted, the elevation of fairness to the status of substantive principle in the case law of the CJEU has possibly far-reaching implications for the EU legal discourse. In the realm of EU-level consumer disputes, fairness parlance has naturally blended with issues of social justice and economic recovery and with the constitutional protection of fundamental rights. Thematically and structurally, such connections are crucial. ${ }^{43}$ The regulation of private autonomy at the EU level - the very podium on which fairness has been promoted to the rank of general principle - is an important part of serious reflections on equality, and on the lack of it. ${ }^{44}$ Recent contributions to the literature on inequality in the Western world have shed light on the fact that returns on capital (Piketty) or on real property (Stiglitz) have been much higher in modern times than economic growth. Such spectacular returns have created an ever deeper chasm between rich and poor, with dire consequences for republican ideals and for democracy itself. A necessary complement to such macro-economic vehicles of inequality is to be found in contract law, which to this day rewards higher bargaining power, enables larger-than-growth returns for "the haves," 45 and exerts a constant upward pressure on the Gini coefficient. "Fairness" is code for all the ways in which such dynamics might be controlled at law, and is therefore an inherent part of contemporary equality discourse in law, politics, and beyond.

The emergence of general principles of law in the jurisprudence of the CJEU has raised questions of federalism and institutional competence. ${ }^{46}$ Scholars have debated whether contract law in particular is sufficiently harmonized at the EU level as to express truly common principles and, if so, whether it is proper for the CJEU - as opposed to legislatures or other

\footnotetext{
43 See, eg, HW Micklitz and I Domurath (eds), Consumer Debt and Social Exclusion in Europe (Ashgate, 2015).

44 JE Stiglitz, The Price of Inequality: How Today's Divided Society Endangers Our Future (W.W. Norton \& Company, 2013); T Piketty, Capital in The 21th Century (Belknap Press, 2014).

${ }^{45}$ M Galanter, 'Why the "Haves" Come Out Ahead: Speculations on the Limits of Legal Change' (1974) 9 Law and Society Review 1.

46 See, eg, S. Weatherill, "The "Principles of Civil Law" as a Basis for Interpreting the Legislative Acquis' (2010) 6 European Review of Continental Law 74; AS Hartkamp, 'The General Principles of EU Law and Private Law', (2011) 75 RabelsZ 241; Hesselink, 'The General Principles of Civil Law: Their Nature, Roles and Legitimacy’; N Reich, General Principles of EU Civil Law (2014).
} 
epistemic communities ${ }^{47}$ - to name and define them. ${ }^{48}$ Others have ably tackled this larger debate. ${ }^{49}$ It may therefore suffice here to note that, at least with regard to the principle of fairness in private law, such concerns seem unfounded. In line with acquired interpretive principles of civil law, general principles are judicial tools but need not be judicial creations, and have historically coexisted with utterly formalist conceptions of adjudication. ${ }^{50}$ As elements of closure, they must be derived by induction from positive legal norms. Fairness is by now fully reflected in many corners of the consumer legislative acquis and is definitely ready for judicial consumption. Invoking fairness as a general principle of (EU) civil law is no sign of impermissible activism. ${ }^{51}$

E Friz attests to the possibility of discursive osmosis across the private/public divide in a way that does not disrupt the relative autonomy of private law. The type of fairness embraced by the $E$ Friz Court speaks to broader, systemic issues of the EU legal order, but it does not ignore the distinction between principles of civil law and higher-order principles of European constitutional law. ${ }^{52}$ It only allows the practice of private law adjudication to radiate meaning and to perform a constitutionally appropriate expressive function.

Put simply, the embrace of a particular rhetorical mode in the adjudication of contract disputes may amplify the relevance of certain concerns and enhance their weight beyond the courts, well into the political arena. In better words,

The politics of contract technicality [...] is an ideological and rhetorical, rather than a directly distributive politics. In discussing

47 Such as the bodies responsible for the development of the PECL or the DCFR. See Hesselink, 'The General Principles of Civil Law: Their Nature, Roles and Legitimacy' 167 and 175.

48 See M Claes, 'The European Union, its Member States and their Citizens' in D Leczykiewicz and S Weatherill (eds), The Involvement of EU Law in Private Law Relationships 29.

${ }^{49}$ See J Basedow, 'The Court of Justice and Private Law: Vacillations, General Principles and the Architecture of the European Judiciary' (2010) 18 European Review of Private Law 443, 456; Guido Alpa, 'General Principles of Law' (1994) Annual Survey of International and Comparative Law.

${ }^{50}$ The Italian experience with general principles during and after fascism attests to the compatibility between general principles in private law adjudication and formalist understandings of legal interpretation. See Alpa (n 49); S Vogenauer, “'General Principles' of Contract Law' in L Gullifer and S Vogenauer (eds), English and European Perspectives on Contract and Commercial Law: Essays in Honour of Hugh Beale 291, 293-299 (Hart Publishing, 2014); E Hondius, 'Principles and the Law' (2012) 20 European Review of Private Law 289, 291 ("The Italian Codice Civile of 1942 is the only modern Civil Code to use principles explicitly.”).

${ }^{51}$ H-W Micklitz, 'Mohamed Aziz - Sympathetic and Activist, but did the Court Get it Wrong?' in A Sodersten and JHH Weiler (eds), Where the Court Gets it Wrong (2013).

${ }^{52}$ See M Dougan, 'The Impact of the General Principles of Union Law upon Private Relationships' in Leczykiewicz and Weatherill (eds), The Involvement of EU Law in Private Law Relationships 71 (firmly restating this distinction). 
technical issues, legal scholars make arguments, and these arguments "resonate" with, or are homologous with, or are mutually reenforcing vis-à-vis arguments in domains conventionally thought to be political rather than merely technical.... If contract law requires businessmen of equal bargaining power to look out for one another, then it is more plausible that public law should require strong groups to look out for weak ones. ${ }^{53}$

Recent literature has portrayed the dialogue between Spanish courts and the CJEU as a serious challenge to the austerity politics embraced in Madrid, both by means of preliminary references and in the context of contract disputes. ${ }^{54}$ This portrait, if correct, illustrates the power of principle in private law adjudication. Courts engaged in the discussion of substantive fairness are on one hand only solving atomistic contract disputes; on the other hand, by striving to promote fairness between private parties, their judgments become an important element in their natural epistemic landscape.

The CJEU can perform this important expressive role without invoking constitutional precepts or rehashing legislative debates, but simply building on the solid jurisprudential tradition of culling principles from within private law rules. Fully framed by the legislator through rules of private interaction, and then developed organically from within, the principles of private law may hold superior legitimacy exactly because of their merely indirect reference to the rest of the legal and political order. ${ }^{55}$ Rather than being influenced by ideology, they can safely radiate from the inside out.

A comparison with the U.S. experience, where fairness as a principle or policy carries diminishing weight in adjudication and is no longer central to judicial culture, seems to recommend exactly this course of judicial action.

5. Fairness in U.S. Contract Law: Rise and Fall

\footnotetext{
53 D Kennedy, 'The Political Stakes in "Merely Technical" Issues of Contract Law' (2002) 10 European Review of Private Law 7.

${ }^{54}$ F Gomez-Pomar and K Lyczkowska, 'Spanish Courts, the Court of Justice of the European Union, and Consumer Law’ (2014) 4 InDret (noting an increase in preliminary references from Spanish courts concerning the compatibility of Spanish rules with Directive 93/13, and finding that such references "[change] the strategic interaction between the Spanish Government and the courts” with regard to the protection of mortgage debtors); FE de la Rosa, 'The Treatment of Unfair Terms in the Process of Foreclosures in Spain: Mortgage Enforcement Proceedings in the Aftermath of the ECJ's 'Ruling of the Evicted”' (2015) 2 ZEuP 366.

55 The doctrine of mistake, for instance, is an old device by which certain jurisdictions have since time immemorial provided shelter for the unwary. H Collins, The Law of Contract 4th edn (Cambridge University Press, 2003) 276.
} 
In order to facilitate transatlantic comparison, it is essential to outline and debunk canonical distinctions. The idea that courts should be guided, when adjudicating private disputes, by meta-principles of justice has a particular pedigree in continental Europe - one that is notably lacking in U.S. law. Judge-made law is anathema to the civilistes because the system cannot have holes and must contain all answers. ${ }^{56}$ When judges encounter a gap or ambiguity in positive law, they need to find guidance in principles that are inherent to their legal order, and that manifest themselves as obvious, pervasive themes in all expressions of legitimate authority. General principles aptly ensure the closure and completeness of the system. This assumption of closure is not typical of the common law and is definitely not essential in U.S. contract law. Organic growth and adaptability staples of the common law - would be impaired if judges were to find solutions exclusively inside the box of written rules and precedents. As a matter of course, U.S. contract law does not use the label of general principles in the way EU judges do. ${ }^{57}$

So much for clichés. In practice, the need to convey objectivity and restraint in court is as much a necessity in the United States as it is elsewhere. ${ }^{58}$ The fact that many judicial posts are filled by virtue of election or executive appointment makes it especially important for the bench to dispel any impression of ideological bent. Decisions informed by "public policy" - an acceptable criterion of last resort in U.S. contract adjudication $^{59}$ - demonstrate the extent of this judicial angst: in their opinions, judges take pains to list a series of legislative, judicial and executive practices that substantiate the particular policy they are embracing. Only if the whole legal system seems to be pointing in a given

${ }^{56}$ Art. 4 of the Code Civil Napoleon (1804) provides that a judge who refuses to give judgment on the pretext that legislation is silent, obscure or insufficient, may be prosecuted for denial of justice. The various historical vicissitudes of the several European states have added nuance to this basic concept, but have not eliminated it. The reference to general principles as mechanisms of closure and gap-filling also derives from the philosophy of liberal state codifications in the $19^{\text {th }}$ century - one of complete break with natural law, custom, and residual norms of Jus Commune - with the result that no solution of a dispute between private parties can find its source beyond the confines of positive codification.

${ }^{57}$ But see, Antonin Scalia, 'The Rule of Law as a Law of Rules' (1989) University of Chicago Law Review 1175 (lamenting the absence of general principles in US constitutional adjudication); Edwin Patterson, 'Cardozo's Philosophy of Law' (1939) 88 University of Pennsylvania Law Review 71 (“[Benjamin Cardozo’s] search for principles of value behind precedents resembles the agelong search for natural law.”).

${ }^{58}$ D Kennedy, A Critique of Adjudication [fin de Siècle] (Harvard University Press, 1998) $1-2$.

59 "In weighing a public policy against enforcement of a term, account is taken of [...] the strength of that policy as manifested by legislation or judicial decisions[.]” Restatement (Second) of Contracts § 178(3) (1981). See DA Friedman, 'Bringing Order to Contracts against Public Policy’ (2012) 39 Florida State University Law Review (noting that "public policy defenses that specify a violation of a statute or regulation tend to be twice as successful than those that appeal broadly to public policy.”). 
direction can the judge adopt a corresponding policy as guiding criterion. ${ }^{60}$ Findings of public policy, just like general principles in Europe, are cast in terms of judicial restraint. ${ }^{61}$ Hennigsen $v$. Bloomfield - a famous case decided at the dawn of the 1960s - provides a clear instance of this practice. In its opinion, the Supreme Court of New Jersey noted that the contract signed by the purchaser of a defective automobile might be sufficiently conscionable in a technical, doctrinal sense, and yet it was to be partly voided - i.e. purged of exculpatory clauses - in light of a general trend towards heightened consumer protection and responsible manufacturing. ${ }^{62}$ This trend found ample, 'objective' documentation in the draft Uniform Commercial Code and New Jersey's Uniform Sale of Goods Act. ${ }^{63}$ The public policy that enabled judicial voidance of a contract clause was 'discovered' in the legal system at large, and avowedly not concocted in or by the court. In such judgments, it is apparent that public policy in U.S. courts is a functional equivalent of the general principle of fairness invoked by the CJEU in the E Friz judgment. ${ }^{64}$

Further equivalents emerged around the same time. In the late 1960s, following the path-breaking case of Williams $v$. Walker-Thomas ${ }^{65}$ and against the background of rising pro-consumer activism, ${ }^{66}$ the idea of substantive fairness in contract law adjudication came to be embedded in unconscionability analyses. The old equitable remedy grew into a versatile tool for policing unfair contract clauses in court, and for a while it allowed judges to redress business' overreach in consumer contracts. ${ }^{67}$

In order to achieve substantive fairness through contract adjudication, courts would also refer to economic and political phenomena that upset the original balance of interests between the parties to a contract. Still into the 1990s, a time of welfare contraction in the U.S., it was not uncommon

60 See, eg, Matter of Baby M, 109 N.J. 396, 537 A.2d 1227 (1988); Henningsen v. Bloomfield Motors, Inc., 32 N.J. 358, 161 A.2d 69 (1960).

${ }^{61}$ See J. Lipshaw, 'Formalism, Scientism, and the M-Word: A Comment on Professor Movsesian's Under-Theorization Thesis’ (2006-2007) 35 Hofstra Law Review 23, 30 (posing the question, "[w]hy, if we all acknowledge we are now legal realists, and the law is the product of social, personal and political influences, do we, as lawyers and judges, continue to speak of the law as though it were there to be discovered, à la Langdell or Williston, preexisting but untapped, the work of some unnamed Author?”).

62 See PA Alces, A Theory of Contract Law: Empirical Insights and Moral Psychology (Oxford University Press, 2011) 129-33.

${ }^{63}$ Henningsen, 32 N.J. at 386 (speaking of the Uniform Sales Act); ibid 404 (speaking of the Uniform Commercial Code).

${ }^{64}$ I use the concept of functionalism in the loosest possible sense, as an enabler of comparison. See R Michaels, 'The Functional Method of Comparative Law' in The Oxford Handbook of Comparative Law (2006) 339 (offering an insightful dissection of the concept and positing its lasting usefulness).

65 Williams v. Walker-Thomas Furniture Co., 350 F.2d 445 (D.C. Cir. 1965).

${ }^{66}$ President John F. Kennedy, Special Message to the Congress on Protecting Consumer Interest (Mar. 15, 1962).

${ }^{67}$ Anne Fleming, 'The Rise and Fall of Unconscionability as the 'Law of the Poor' (2014) 102 Georgetown Law Journal 1383. 
for courts to name growing unemployment, and reduced choice for wouldbe employees, as additional reasons to invalidate restrictive terms in employment contracts; or to highlight the increased need for child-care services, resulting from mothers' early return to work, as a reason to void exculpatory clauses drafted by child-care providers. ${ }^{68}$

In contrast to such past trends, the current landscape of contract adjudication is much less inclined to embrace any functional equivalent of a fairness principle in adjudication. ${ }^{69}$ Today U.S. courts take little advantage of the adjudicatory tools in their arsenal - such as public policy, unconscionability, or impracticability - to redress the uneven spread of losses in post-crisis markets. Residual efforts of this kind are visible in some states more than others. ${ }^{70}$ More often, judges cling to the formalist enforcement of contracts as written. ${ }^{71}$ Substantive justice can sometimes be achieved nonetheless, for example via rules of formation that simply leave out of the deal its most unfair clauses. ${ }^{72}$ But there is general agreement, among scholars, that fairness per se carries diminishing

68 D Caruso, 'Contract Law and Distribution in the Age of Welfare Reform' (2007) 49 Arizona Law Review 666.

${ }^{69}$ See S Landrum, 'Much Ado About Nothing?: What the Numbers Tell Us About How State Courts Apply the Unconscionability Doctrine to Arbitration Agreements' (2014) 97 Marquette Law Review 751; P MacMahon, 'Good Faith and Fair Dealing as an Underenforced Legal Norm’ (2015) 99 Minnesota Law Review 2051.

${ }^{70}$ A quick count of the contract cases that address explicitly the issue of "unfair terms" and contractual "fairness" finds West Virginia at the top of the list. The West Virginia Supreme Court of Appeals has indeed actively policed unfair contract terms. See Brown ex rel. Brown v. Genesis Healthcare Corp., 228 W. Va. 646, 724 S.E.2d 250 (2011); Brown v. Genesis Healthcare Corp., 229 W. Va. 382, 729 S.E.2d 217 (2012) (Brown II) (concerning the validity of pre-dispute arbitration clauses in nursing home contracts). This trend has met with reproach at the US Supreme Court. See Marmet Health Care Ctr., Inc. v. Brown, 132 S. Ct. 1201, 1203-04 (2012) ("West Virginia’s prohibition against predispute agreements to arbitrate personal-injury or wrongful-death claims against nursing homes is a categorical rule prohibiting arbitration of a particular type of claim, and that rule is contrary to the terms and coverage of the FAA"). A similar judicial trend is visible in California. See TH Riske, 'No Exceptions: How the Legitimate Business Justification for Unconscionability Only Further Demonstrates California Courts' Disdain for Arbitration Agreements’, (2008) 2008 Journal of Dispute Resolution 591.

${ }^{71}$ See GM Cohen, 'The Financial Crisis and the Forgotten Law of Contracts' (2012-2013) 87 Tulane Law Review 1 (critically stating that "[m] ost discussions to date of possible responses to the financial crisis ignore contract law. To the extent contract law makes an appearance, the assumption is usually that the contracts at issue should and will be strictly enforced, so there is not much more to say. Contract law, however, is not dead. Nor is it impotent; it has just been forgotten.”).

${ }^{72}$ Klocek v. Gateway, Inc., 104 F. Supp. 2d 1332 (D. Kan. 2000) (holding that terms -in this case an arbitration clause received with a product - do not become part of the contract unless the non-merchant buyer expressly agrees to them). But see Hill v. Gateway 2000, Inc., 105 F.3d 1147 (7th Cir. 1997). 
judicial weight. ${ }^{73}$ The U.S. Supreme Court has spoken with particular clarity against voiding 'unfair' arbitration clauses in contract disputes. ${ }^{74}$

\section{Fairness out of court in U.S. Law and Policy}

Aware of the reluctance of many jurisdictions, and of the U.S. Supreme Court, to rein in freedom of and from contract, pro-consumer activism has largely abandoned court-centered strategies. The task of pursuing fairness goals in U.S. contract law has been embraced more directly via legislation and executive action. In U.S. academic circles, the aftermath of 'Lehman Brothers' has been hailed by pro-consumer jurists as "a time of momentous and transformational change in the world of consumer law."75 The drastic changes have resulted not from a strengthened judicial policy of fairness in contract cases, but rather from the spectacular success of proconsumer politics in Washington DC. The recent establishment of a new federal agency, the Consumer Financial Protection Bureau (CFPB), has been noted as a notable shift from the reality of pre-crisis America, characterized by little concern for vulnerable market participants and by the relative triumph of autonomy in federal adjudication. ${ }^{76}$

Interestingly, this shift has downplayed soft principles like fairness and has instead emphasized hard numbers. Establishing the CFPB required the political left (championed by Massachusetts Senator Elizabeth Warren) to ally with Chicago-trained law \& economics scholars so as to ground the case for financial regulation on narrow and fully documented examples of market failure. ${ }^{77}$

Another, more local example of executive mobilization towards fairness is to be found in California's Uber saga. Unfair terms imposed by Uber Technologies, Inc. on its drivers could not be successfully challenged in

\footnotetext{
${ }^{73}$ J Feinman, Un-Making Law: The Conservative Campaign to Roll Back the Common Law (Beacon Press, 2005) (generally deploring the implosion of fairness in court). cf O BenShahar, 'Fixing Unfair Contracts' (2011) 63 Stanford Law Review 869 (confirming that U.S. courts interfere with unfairness very little, but arguing that they do so for good reason). ${ }^{74}$ Rent-A-Car., W., Inc. v. Jackson, 561 U.S. 63, 130 S. Ct. 2772, 177 L. Ed. 2d 403 (2010); AT\&T Mobility LLC v. Concepcion, 131 S. Ct. 1740, 179 L. Ed. 2d 742 (2011); CompuCredit Corp. v. Greenwood, 132 S. Ct. 665, 181 L. Ed. 2d 586 (2012); Am. Exp. Co. v. Italian Colors Rest., 133 S. Ct. 2304, 186 L. Ed. 2d 417 (2013).

75 JA Spanogle and others (eds), Consumer Law: Cases and Materials, 4th edn (West Academic Publishing, 2013) V (noting the enactment of "ground-breaking federal consumer protection legislation ... in the wake of the financial crisis.”).

76 ibid (including the 1991 preface, which describes a desolate landscape: unconscionability deflated in court and used more by corporations than individuals, a notably inactive FTC, deregulation and federal preemption of state usury laws, and only little solace in the Baby FTC Acts, meant to compensate for FTC inaction).

77 O Bar-Gill and E Warren, 'Making Credit Safer' (2008) 157 University of Pennsylvania Law Review 3.
} 
court, ${ }^{78}$ but could be affected by the California Labor Commission, which in June 2015 held that drivers are employees, not independent contractors, and as such find protection in statutory employment law. ${ }^{79}$

More generally, an important strand of legal academia, recommends turning to consumer activism so as to reverse the business-friendly treatment of unfair boilerplate terms where it most matters, i.e. in the forum of public opinion. ${ }^{80}$ Because the idea of judicial fairness has fallen to the margins of pro-consumer discourse, fairness battles must be fought on broader political grounds.

Such changes are momentous and need careful evaluation. At a glance, the decline of fairness as a principle in U.S. contracts adjudication might not seem problematic. After all, a rhetorical emphasis on fairness remains compatible with a narrow reading of the concept, leading to the enforcement of many contract clauses of questionable distributive valence. $^{81}$ Fairness is obviously a malleable concept. ${ }^{82}$ In the U.S. Congress, fairness arguments have been used, for example, to reduce rather than expand the possibility of consumer class actions. ${ }^{83}$ Most worryingly, fairness parlance in court can "increase the appearance of...relative justice of the status quo"84 and so prevent the gathering of political consensus around the need for reform. ${ }^{85}$ It might very well be, therefore, that a social justice agenda in U.S. contract law is better served by activist engagement with legislative and executive bodies than by nostalgic revivals of fairness-based adjudication. Much contract law happens anyway outside of the judicial arena, in private fora for dispute

\footnotetext{
${ }^{78}$ O'Connor v. Uber Technologies, Inc., 58 F. Supp. 3d 989 (N.D. Cal. 2014).

${ }^{79}$ Berwick vs. Uber Technologies, Inc., Case No. 11-46739 EK (2015).

80 "Consumer activism in the form of dissent and voice through Internet and other channels is the heart of the solution." S Ghosh, 'Against Contractual Authoritarianism' (2014) 44 Southwestern Law Review 239. See generally Faircontracts.org, http://faircontracts.org (Ralph Nader’s project).

81 "A bargain is not unconscionable merely because the parties to it are unequal in bargaining position, nor even because the inequality results in allocation of risks to the weaker party.” Troy Mining Corp. v. Itmann Coal Co., 176 W. Va. 599 (1986) (quoting Restatement (Second) of Contracts $\S 234 \mathrm{cmt}$. d at 111 (10th Draft No. 5, 1970)).

82"Perhaps the concept of good faith takes on so many different meanings in different contexts because at base it is nothing more than a requirement of fairness - a definition so broad as to be virtually meaningless.” R Hillman, 'Policing Contract Modifications under the UCC: Good Faith and the Doctrine of Economic Duress' (1979) 64 Iowa Law Review 849, 877.

${ }^{83}$ G Calabresi, 'Class Actions in the U.S. Experience: The Legal Perspective' in JG Backhaus, A Cassone and GB Ramello (eds), The Law and Economics of Class Actions in Europe: Lessons from America (Edward Elgar Publishing, 2012) (discussing the Class Action Fairness Act of 2005).

${ }^{84}$ Kennedy (n 58) 2.

85 "From the perspective of the law school contracts classroom, it might appear that contract law requires people to be fair to one another. But many judge-made rules of contract law that purport to give weak parties protections against strong parties turn out to be illusory in practice.” ibid 270 (footnote omitted).
} 
resolution as well as in a growing number of self-regulating communities. $^{86}$

There are, however, significant problems with the ongoing shift away from judicial fairness. First, in sectors in which there is no legislative will to pursue redistributive fixes, the relaxation of fairness as a guiding judicial principle leaves weaker parties entirely out in the cold. ${ }^{87}$ Employment contracts in the low-wage sector, for instance, are unlikely to be legislatively regulated any time soon, yet are replete with unfair terms that could use more judicial policing in many jurisdictions. ${ }^{88}$ Second, in so far as courts remain repositories and propagators of values in the United States, the decline of fairness as a guiding principle in contract law adjudication is an alarming trend. ${ }^{89}$ Third, as evidenced by the genesis of the CFPB, empiricism in contract law is on the rise. Scholars traditionally concerned with fairness towards consumers and with protection of weaker parties resort to field experiments more and more often, and they feel compelled to support their objections to untrammeled freedom of contract with tangible evidence of systemic unfairness. ${ }^{90}$ The shift is evidentiary: the type of empiricism now in vogue assumes that the market is efficient and capable of redressing unfair contractual practices through self-healing, competitive market mechanisms. Only when the opposite is proven, not just by a plethora of anecdotes, and not even by bold examples of contractual overreach, ${ }^{91}$ but by extensive field work, ${ }^{92}$ can regulation be tolerated at the margins. In this climate, resorting to "considerations of

${ }^{86}$ F Cafaggi, 'Self-regulation in European Contract Law' (2007) 1 European Journal of Legal Studies 1.

${ }^{87}$ R Arnow-Richman, 'Cubewrap Contracts: The Rise of Delayed Term, Standard Form Employment Agreements' (2007) 49 Arizona Law Review 637.

88 See, generally V Moffat, 'Making Non-Competes Unenforceable' (2012) 54 Arizona Law Review 939. Professor Rachel Arnow-Richman deems it unlikely that a bill recently introduced in the U.S. Senate (the M.O.V.E. Act) will make it through the legislative process in the present political climate. E-mail from Rachel Arnow-Richman, Professor at University of Denver Sturm College of Law, to AALS Contracts List Serve (June 6, 2015) (on file with author).

${ }^{89} \mathrm{~J}$ Resnik, 'Fairness in numbers: A Comment on AT\&T v. Concepcion, Wal-Mart v. Dukes, and Turner v. Roger' (2011) 125 Harvard Law Review 78 (“Courts in democratic social orders are [...] one of several venues in which the content of law is debated, and other branches of government may, in turn, respond.”); MJ Radin, Boilerplate: The Fine Print, Vanishing Rights, and the Rule of Law (Princeton University Press, 2014).

90 See, eg, I Ayres and A Schwartz, 'The No-Reading Problem in Consumer Contract Law' (2014) 66 Stanford Law Review 545.

${ }^{91} \mathrm{~J}$ Resnick, 'Diffusing Disputes: The Public in the Private of Arbitration, the Private in Courts, and the Erasure of Rights' (2015) 124 Yale Law Journal 2804 (2015) (“We may change any terms, conditions, rates, fees, expenses, or charges regarding your Services at any time.” - Wireless Provider "Customer Agreement.”).

92 Consumer Financial Protection Bureau, 'Consumer Financial Protection Bureau Finds that Arbitration Agreements Limit Relief for Consumers' (Aug. 1, 2015), files.consumerfinance.gov/f/201503_cfpb_factsheet_arbitration-study.pdf (finding that few consumers obtain individual relief through arbitration and the courts; therefore, arbitration agreements limiting class actions greatly diminish the possibility for relief.). 
equity and fairness"93 in contract law adjudication comes to sound somewhat old-fashioned, and so does the idea of capturing the economic reality of contracts by focusing exclusively on what happens in court. The residual cohort of scholars involved in promoting considerations of fairness in U.S. courts' adjudication finds a formidable obstacle in the new empiricist trend. ${ }^{94}$ The ALI reporters recently tasked with drafting a Restatement of Consumer Law are dedicated empiricists, ${ }^{95}$ who have often used economic arguments to prove the irrelevance of existing regulation, ${ }^{96}$ and have been trained in the conviction that pursuing equitable redistribution via judicial fairness is passé. ${ }^{97}$ In this climate, fairness projects are likely to remain isolated phenomena, rather than part and parcel of contract law.

\section{Towards a Fair Division of Risks in Post-Crisis EU Adjudication}

If compared to the tough stance of the U.S. federal judiciary towards the ongoing plight of American consumers, the attitude of the CJEU in matters of contractual fairness looks remarkably emotive and empathetic. ${ }^{98}$ The CJEU has been guided by a series of statutory provisions (secondary legislation), some clearly aimed at regulating contracts through private law rules (in primis the UCT directive), others designed to prompt administrative control (such as the UCP directive) but no less helpful towards defining what counts as fair between two parties. Its judgments have grown increasingly sensitive to the drama of financial markets' collapse and of austerity measures. In Aziz, in particular, the Court began to show real concern for the irreversible, traumatic loss of one's dwelling in the course of swift execution procedures, in a legal landscape that left little room for suspension orders and at a time of sudden decline in the value of mortgaged property. ${ }^{99}$ Importantly, Aziz also prompted legislative

93 Jacob \& Youngs, Inc. v. Kent, 129 N.E. 889, 890-91 (1921). In this case, considerations of fairness famously led Judge Cardozo to interpret an express condition so as to avoid the 'unjust' forfeiture of a significant sum of money. Forfeiture would have resulted from a formalist reading of the contract. A recent survey of doctrinal possibilities aimed to redress the practice of unfair terms in standardized contracts is to be found in N Kim, Wrap Contracts: Foundations and Ramifications (Oxford University Press, 2013).

${ }^{94}$ Radin (n 89); Arnow-Richman (n 87).

95 O Ben-Shahar, F Marotta-Wurgler \& O Bar-Gill (Reporters), 'Restatement (Third) of Consumer Contracts', American Law Institute, (last accessed Nov. 2, 2015), www.ali.org/projects/show/consumer-contracts/.

${ }^{96}$ See, eg, O Ben-Shahar \& C E. Schneider, More than You Wanted to Know: The Failure of Mandated Disclosure (Princeton University Press, 2014).

${ }^{97}$ S Shavell and L Kaplow, Fairness versus Welfare (Harvard University Press, 2006).

${ }^{98}$ Micklitz (n 51).

${ }^{99}$ Case C-415/11 Mohamed Aziz v. Caixa d’Estalvis de Catalunya [2013] ๆ [61]. See also Case C-169/14 Sánchez Morcillo \& Abril García v. Banco Bilbao Vizcaya Argentaria SA [2014] EU:C:2014:1388, Order of the President of the Court of 5 June 2014 I [11]; Case C-34/13 Kušionová v. SMART Capital [2014] ๆ [63] ("The loss of a family home is not only such as to seriously undermine consumer rights[,] but it also places the family of the 
reform in Spain aimed at enhancing the protection of debtors in the real estate market. ${ }^{100}$ The general principle most used to do justice to consumers turns out to be the EU law principle of effectiveness used as guidance in interpreting the UCT directive, not the civil law principle of fairness invoked in E Friz. However, boosting the effectiveness of fairness control via general principles is arguably the same as reinforcing the principle of fairness itself.

The UCT directive has come to life with a force and prominence that would have been hard to anticipate when it was adopted. ${ }^{101}$ The resulting case law has been amply praised as a fountain of social justice in times of drought, to the point of prompting parallels between today's CJEU and the Warren Court ${ }^{102}$ - a remarkable makeover for a court charged with Lochnerism in other contexts. ${ }^{103}$ This line of judgments has also led several scholars to fear back-lash effects, ${ }^{104}$ to question the propriety of the Court's foray into political ground, ${ }^{105}$ or at least to argue that the Court went as far as it could. ${ }^{106}$ Oliver Gerstenberg, in particular, has carefully recounted the many institutional constraints within which the Court must operate when interpreting the UCT directive for the benefit of national courts. First, the CJEU cannot trespass horizontal boundaries, i.e. it cannot usurp the role of the EU legislator. Second, the CJEU must limit itself to the task of interpretation, as opposed to applying the law to the facts; applying the law to the facts is a task reserved to the national courts, especially when the text of reference is one of minimum harmonization. Third, the CJEU must respect the internal integrity of member states' private laws, and therefore, must not turn all private law disputes into constitutional questions. Fourth, the CJEU must avoid engaging directly with the politics of solidarity, both because it is only a court and because

consumer concerned in a particularly vulnerable position[.]”). Note that, while in Aziz the Court and AG Kokott avoided direct references to housing as a socio-economic right, such references are quite explicit in the more recent cases.

100 The Spanish reform has already been itself the object of scrutiny in Luxembourg. See C-482, 484, 485 and 487/13.

${ }^{101}$ N Reich and H-W Micklitz, 'The Court and Sleeping Beauty: The Revival of the Unfair Contract Terms Directive (UCTD)’ (2014) 51 Common Market Law Review 771.

102 Micklitz (n 51).

103 D Nicol, 'Europe’s “Lochner” Moment’ (2011) 2011 Public Law 308; Christian Joerges, 'Justice within and between Polities’ Verfassungsblog, (June 10, 2015); D Caruso, 'Lochner in Europe: A Comment on Keith Whittington's "Congress Before the Lochner Court”' (2005) 85 Boston University Law Review 867.

${ }^{104}$ Micklitz (n 51). Backlash effects are already visible. See Kušionová, [2014] Case C34/13; Case C-482/12 Macinský v. Getfin SRO Financreal SRO [2013] (AG opinion). See F Della Negra, 'The Uncertain Development of the Case Law on Consumer Protection in Mortgage Enforcement Proceedings: Sánchez Morcillo and Kušionová' (2015) 52 Common Market Law Review 1009, 1031 (concluding that with Kušionová the Court went too far back from Aziz).

105 Micklitz (n 51).

${ }^{106}$ Gerstenberg (n 10) 614-620. 
the EU as a system is not endowed with necessary competences in matters of welfare. ${ }^{107}$

Yet, it can be argued that the Court is not taking full advantage of the space allowed for by the legislative acquis of consumer protection. ${ }^{108}$ Recent judgments and opinions indicate a less than full embrace of the private law principle of fairness in Luxembourg. This hesitation is uncalled for. There is ample support, in the regulation of private autonomy stemming from EU legislation, for a general principle of fairness in EU private law. The basic idea that weaker parties should not be hoodwinked, that their inaction should not be exploited, and that every time there is room for interpretation the judge should lean in a direction that prevents the enrichment of parties with higher bargaining power, is an idea firmly built in the architecture of EU private law. This solid base should lend ample credibility to fairness as a principle with teeth.

The mandate of fairness in consumer transactions took explicit legislative form exactly because of the realization that freedom of contract, which to this day is the backbone of the internal market, leads normally to imbalanced terms in B2C standard forms, and needs regulatory control precisely towards the goal of enabling true autonomous choices for both sides - traders and consumers. ${ }^{109}$ Yet the Court seems eager to remind itself and others that fairness control remains an exception, to be interpreted with care and restraint. This seems to be the case especially in the context of AG opinions, which is where deep judicial rationales can surface. ${ }^{110}$ It is as if Aziz brought the Court to the edge of the judicial cliff, causing panic and retreat. For instance, even in a remarkably proconsumer opinion, substantially followed by the Court in Kásler, AG Wahl took pains to drop an uncalled-for reminder that freedom of contract is paramount:

104. While fully aware that this question was not referred directly and specifically to the Court, and that it has not, therefore, been discussed by the parties[,] I think that it is important to stress that [...] the purpose of the court's intervention must, as far as possible, be simply to reestablish a degree of equality between the sellers or suppliers and the consumers with whom they conclude contracts[.] 105. It must not lead to the upsetting of the contractual balance through the intervention by a State authority after the contract has been

\footnotetext{
107 ibid.

108 "Under EU law, the right to accommodation is a fundamental right guaranteed under Article 7 of the Charter that the referring court must take into consideration when implementing Directive 93/13.” See Kušionová, [2014] Case C-34/13 at ๆ 65.

${ }^{109}$ C- 280/13 Barclays Bank v. Sara Sanchez Garcia and Alejandro Chacon Barrera [2014] EU:C:2014:279, ๆ [32].

${ }^{110} \mathrm{M}$ Lasser, Judicial Deliberations: A Comparative Analysis of Transparency and Legitimacy (Oxford University Press, 2009).
} 
concluded. [...A]ny intervention by a third party, including the State in its legislative function, must be viewed with caution in so far as it could potentially jeopardise the freedom of contract and the free competition which are its corollary. ${ }^{111}$

Consider, another passage, intended by AG Wahl to premise his discussion of mortgaged property repossession in Slovakia (Macinský):

60. As the global financial crisis from which Europe and the rest of the world is slowly recovering shows, a well-functioning and healthy credit system is one of the cornerstones of an open market economy. This may lead legislatures to devise particular security and enforcement schemes which are more or less favourable to the business sector in order to support the credit system. The case under consideration raises the question as to whether the procedure at issue goes too far in favouring traders over consumers. ${ }^{112}$

These are worrisome quotes. Framing the analysis in these terms is not in line with the spirit of the UCT directive, its focus on weakness and vulnerability, and its function as a bulwark against the predictably inequitable effects of sheer market forces. The point is not that vulnerabilities among traders should be disregarded - indeed, the practice of distributive analysis requires consideration of such issues in context. ${ }^{113}$ But it is hard to see what a healthy credit system has to do with cut-throat debt collection practices. There is general consensus across ideological camps that the global financial crisis resulted not from the suppression of private autonomy, but rather by excessively permissive regimes. Monitoring the overreach of business is not a hindrance, but rather a condition towards achieving a healthy credit system. The balancing opportunity provided by the fairness test is, in the AG opinion, distorted by vulgarized versions of laissez-faire economics. The weighing is flawed, and the distributive stakes are therefore deeply misrepresented.

The AG had of course plausible reasons to deem the reference in this case inadmissible (the debtors' claim, once meritorious, was arguably moot by the time the reference reached Luxembourg), but he would also have had ample opportunity to empathize, if not with the defaulting debtors, at least with the referring court. Instead, the referring court was left wondering whether anything in EU law might point to the injustice of Slovakia's execution proceedings. ${ }^{114}$ The AG chose to chide the Slovak court for its

${ }^{111}$ Case C-26/13 Árpád Kásler and Hajnalka Káslerné Rábai v OTP Jelzálogbank Zrt [2013].

112 Macinský, [2013] Case C-482/12.

${ }^{113}$ See Kukovec (n 5), and more generally Fennell and McAdams, 'The Distributive Deficit in Law and Economics' (illustrating counterintuitive distributive effects of legal rules). ${ }^{114} \mathrm{Mr}$. and Ms. Macinský- both retired - had borrowed $€$ 5,000 in April 2011 to face the demands of other creditors. Their lender had quickly transferred the credit to a professional recovery entity, which in turn had charged extravagant default fees (bringing the couple's 
lack of clarity, knowledge, and organization - a choice of tone presumably meant to stem the inflow of references in Luxembourg - and to explain that efficient debt collection is essential to the economic recovery of Europe.

Even bracketing these expressions as dicta and focusing only on instances of empathetic engagement with post-crisis predicaments, it remains unclear whether the contract law emerging in Luxembourg is fully responsive to a principle of fairness - even within an area where the EU legislator has asked the CJEU to set a floor of minimum substantive fairness across the Union. Gerstenberg's analysis shows that, in a deliberative, procedural sense, the Court's case law has adequately served the function of representing multiple interests, prompting detailed justifications of outcomes, and learning from a plurality of national experiences. This is, admittedly, one version of fairness. But recall the core question asked by the Spanish court in Aziz: " $[\mathrm{H}]$ ow is disproportion to be interpreted?"115 Answering this question implies distributive considerations of the type famously embraced by Justice Brennan in Penn Central. Consumer-trader relations can look very different in the various corners of the Union. ${ }^{116}$ In its preliminary rulings, the CJEU should guide national judges to unpack the distributive complexities of each dispute, rather than resorting to empty juxtapositions.

\section{Law and the Dominance of Economic Dogma}

The foregoing pages have built upon the assumption that the CJEU has correctly 'discovered' a general principle of fairness in the relatively selfcontained realm of national private laws and in light of supranational enactments. On this basis, the previous sections have concluded that context-sensitive fairness towards consumers is a welcome proposition, fully ripe for judicial enforcement. Two corollaries accompany this conclusion. First, in speaking against crass abuses of consumers' vulnerabilities, as it did in Aziz and could have done in Macinský, the CJEU duly embraces the idea that fairness and autonomy are fully intertwined. ${ }^{117}$ The private law notion that emerges from fairness-driven adjudication is distinctively thick, articulate, and irreducible. ${ }^{118}$ Second,

debt to over 21,000 by October of the same year) and swiftly called a public auction sale of the Macinskýs’ mortgaged home. Macinský, [2013] Case C-482/12.

115 Aziz, [2013] Case C-415/11.

${ }^{116}$ Kukovec (n 6).

117 See J Singer, No Freedom without Regulation: The Hidden Lesson of the Subprime Crisis (Yale University Press, 2015).

118 H Dagan, 'Autonomy, Pluralism, and Contract Law Theory' (2013) 76 Law and Contemporary Problems 19; H Dagan and M Heller, Freedom of Contracts (Columbia Law and Economics Working Paper No. 458, 2013). 
the fact that a strikingly thin notion of autonomy continues to surface in judicial opinions goes against the grain of specific legislative choices and against positive law in the nation states. Such representations of 'disembedded' autonomy in judicial discourse should not be condoned or praised as expressions of values in deliberative processes and balancing exercises, especially when they may lead to justify aggressive debtcollection and repossession practices.

The resilience of out-of-context references to naked autonomy is a disquieting phenomenon that deserves elaboration. ${ }^{119}$ The EU's intervention in contract law has brought about an enormous expansion of private autonomy, both across borders (via the judicial activation of the four freedoms) and inside domestic markets (via the reduction of state control over a plethora of services and economic activities); ${ }^{120}$ on the other hand, and precisely towards the goal of increasing the volume of transactions, the EU's legislator has enacted new common rules. ${ }^{121}$ Due to curious optical distortions, especially in the wake of recent financial market reforms, EU-level regulation makes a larger impression than autonomy-boosting interventions. As a result, with an ironic flip of Scharpf's asymmetry paradigm, ${ }^{122}$ domestic systems come to be romanticized as cradles of autonomy, while the supranational level is identified with regulatory constraint. ${ }^{123}$ The truth, of course, is otherwise. If contractual autonomy in national private law was ever free of regulatory laches, such halcyon days were certainly over before the inception of the internal market project. ${ }^{124}$ Autonomy has long been welded to other systemic goals in national systems. In the wake of the 1985 White Paper, many private law scholars considered the harmonization of private law a carrier of regulatory dilution - not expansion - and mobilized to contain the regressive distributive effects of such developments. ${ }^{125}$ Fairness won its role of general principle by killing a dragon or two in the EU political

${ }^{119}$ C Crouch, The Strange Non-death of Neo-liberalism (Polity, 2011); V Schmidt and M Thatcher (eds), Resilient Liberalism in Europe's Political Economy (Cambridge University Press, 2013).

${ }^{120}$ G Comparato, 'Private Autonomy and Regulation in the EU Case-Law' in H-W Micklitz, Y Svetiev and G Comparato (eds), European Regulatory Private Law - The Paradigms Tested (EUI Working Paper Law, 2014).

121 ibid ("[P]rivate autonomy gets on the one hand extended, as regulation is meant to construct and enlarge a market in which all operators have an equal access on a nondiscriminatory base, but on the other hand gets subjected to a series of measures which in a traditional private law perspective are qualified as limitations of it[.]").

${ }^{122}$ FW Scharpf, Governing in Europe: Effective and Democratic? (Oxford University Press, 1999) ch 2.

123 OO Cherednychenko, 'Contract Governance in the EU: Conceptualising the Relationship between Investor Protection Regulation and Private Law' (2015) 21 European Law Journal 500.

${ }^{124}$ F Wieacker, A History of Private Law in Europe: with Particular Reference to Germany (Oxford University Press, 1996).

125‘Social Justice in European Contract Law: A Manifesto' (2004) 10 European Law Journal. 
and legal arena, and should not be knocked out of place by callous references to tabloid economics.

This essay's insistence on B2C fairness as positive law with a spine, if not with teeth, is in line with a growing trend towards asserting 'hard law' in private disputes and in other facets of post-crisis Europe. Champions of this trend include scholars with ample training in legal realism, fully conscious of law's pliable nature and definitely uneasy with doctrinal rigidity. The new emphasis on the rule of law as a bulwark of civility in these scholars' writings is intended to protest the superimposition of an economic paradigm of necessity over legal frameworks of welfare, constitutional arrangements and international obligations. Following CJEU and German FCC judgments upholding legal measures aimed at saving the Euro, scholars have tackled the functionalist relaxation of interpretive canons and lamented the subjugation of law to economic dogma. ${ }^{126}$ Along the same lines, others have denounced the sheer illegality of measures brought about by austerity politics and decried, for instance, the many unchallenged breaches of human rights caused by the Troikadriven policies of Greek austerity. ${ }^{127}$

These critiques resonate loudly in the context of this essay. AG Wahl's reminder that a "healthy credit system is one of the cornerstones of an open market economy" relies, worryingly, on the rhetorical appeal of economic necessity: the paramount health of the credit system is invoked to rein in the reach of fairness - a principle of law - in the context of aggressive lending practices. Against such judicial stances, and in line with the just described scholarly trend, this essay has attempted to highlight fairness as the firm line that it should be in accordance with the explicit mandate of secondary EU legislation. ${ }^{128}$ In myriad ways, the private law of the EU has been and should be subject to critique, both internal, as it is riddled with contradictions, and external, given its predetermined agenda, ${ }^{129}$ its uneven impact on different regions of Europe ${ }^{130}$ and its overly narrow focus. ${ }^{131}$

126 "Law must adapt, but must also be constrained by legal reasoning exactly in order to distinguish it from mere political decision-making." M Everson, 'An Exercise in Legal Honesty: Rewriting the Court of Justice and the Bundesverfassungsgericht' (2015) 21 European Law Journal 474, 478.

127 "The way the crises have been governed challenges not only the substantive content of human rights law constitutionally, supranationally and internationally, but notably the very idea that there should be a clear line of responsibility when it comes to the protection of human rights.” M Salomon, 'Of Austerity, Human Rights and International Institutions' (2015) 21 European Law Journal 521.

128 See H Collins, The European Civil Code: The Way Forward (Cambridge University Press, 2008); See also U Mattei, 'Hard Code Now!’ (2002) 2 Global Jurist Frontiers 215 (expressing disenchantment with 'soft' principles of civil law).

${ }^{129}$ M Bartl, 'The Way We Do Europe: Subsidiarity and the Substantive Democratic Deficit’ (2015) 20 European Law Journal 23.

${ }^{130}$ Kukovec (n 6).

131 Caruso (n 9). 
But the kernels of substantive justice that it has yielded thus far should not be crushed.

\section{Fairness and the Perils of Deliberation}

This essay partakes of a post-crisis movement, led by a growing circle of scholars, which clings to law as a bulwark against the rhetoric of economic necessity. But it also calls into question another worrisome feature of EU law, namely the mind-boggling multiplication of 'non-weighted' narratives in EU discourse, which come to be balanced as if they all held equal importance. In the context of the Eurozone crisis, the tale of virtuous Swabian wives, only spending what is already in the pot, has been artfully juxtaposed to alarming reports of southern tragedy, with the rhetorical effect of leveling the two perspectives as if they had an equal claim to distributive justice and as if the difference principle had never entered the universe of political concepts. ${ }^{132}$ The private law quest for fair results in contracts disputes risks being derailed by similar juxtapositions: evicted consumers on one hand, and a credit system in need of efficiency on the other. The fact that in the weighing of such conflicting needs the EU legislator has been placing emphasis on the protection of situationally weaker parties risks getting lost in the balancing game.

The excessive use of such flat juxtapositions may be attributed to two trends. First, proportionality has fully entered the realm of private-law adjudication - a practice by now amply analyzed in the literature; ${ }^{133}$ second, a heartfelt belief in the power of judicial deliberation has gained currency in private law circles. With specific regard to the reading of the UCT directive in Luxembourg, Gerstenberg portrays the Court as laudably engaged in the desirable processes of perfecting, through dialogue with national courts, the meaning of fairness in contract disputes:

[The Court's] experimentalism envisages a circular-recursive and mutually transformative-relationship between general interpretive frameworks and their contextualising application: national courts apply the 'general criteria' to a particular term in the circumstances of a case, but through their references to the CJEU for preliminary rulings also, where appropriate, invite revision of those general criteria in the light of their consequences. Harmonisation occurs ... through always provisional and rolling endorsements, ultimately by

132 D Nicols, 'Swabian Wives, Suffering Southerners: The Contestability of Justice as exemplified by the Eurozone Crisis' in Kochenov and others (eds), Europe's Justice Deficit? (n 4) 165.

133 D Kennedy, 'A Transnational Genealogy of Proportionality in Private Law' in R Brownsword and others (eds), The Foundations of European Private Law (Hart Publishing, 2011) 185. 
the citizens themselves, of emergent paradigm instances of improper contractual terms. ${ }^{134}$

This passage clearly echoes the vast body of literature that falls under the headings of conflicts law, justification, and proceduralization. ${ }^{135}$ Developed over the course of the past two decades on the basis of authoritative philosophical foundations, this body of scholarship posits that the added value of EU law lies in its procedural coordination of conflicting views. EU law provides a system that will tolerate and even foster pluralism in so far as dissonant voices are able to produce justifications for their arguments. When applied to the realm of private law, this view has led to the idea that the Court could continue the process of harmonization beyond the point of legislative consensus. The Court may develop organically, by means of examples, the meaning of intrinsically complex principles such as fairness. In this view, the very design of the CJEU may fuel this process. Because the CJEU contains legal actors from different legal traditions, it inherently forms an agglomerate of divergent worldviews. ${ }^{136}$ The variety of understandings of fairness brought to the bench by such different actors as AGs Trstenjak, Kokott, and Wahl is apt to yield precisely this type of organic accrual.

It is worth noting, however, that hints of perplexity have emerged from within this school of thought. Christian Joerges, after sobering reflections on law in a time of crisis, has more recently conceded that the range of justifications allowed for by the Court is narrow and may actually shut down important voices and values. ${ }^{137}$ To this type of worry one should add, in light of Macinský, the fear that under the guise of pluralism the Court might facilitate the unraveling of hard rules and the unmaking of clear legislative progress. Through Macinský, it is easy to see how the formula of value pluralism can become a victim of its own success, rehashing balancing acts that should have been confined to the legislative arena, and drowning substantive fairness in a sea of justifications.

\footnotetext{
134 Gerstenberg (n 10) 620.

135 J Neyer, 'Justice and the Right to Justification: Conceptual reflections' in Kochenov and others (eds), Europe’s Justice Deficit? 211.

${ }^{136}$ A Cohen and A Vauchez, 'Introduction: Law, Lawyers, and Transnational Politics in the Production of Europe’ (2007) 32 Law and Society Inquiry 1.

137 Joerges, 'Justice within and between Polities' (n 103).
} 